\title{
Visionary Drawings for Weaving Visuals of the City. Roberto Loeb's Design for the International Competition for Ideas for the Recovery of the Le Murate Complex
}

\author{
Ana Tagliari \\ Wilson Florio \\ Luca Rossato \\ Felipe Corres Melachos
}

\section{Abstract}

This paper is a result of a research that investigates architectural designs developed by both Brazilian architects in Italy and Italian architects in Brazil. Thus, this text presents the study of the architectural design of Brazilian architect Roberto Loeb for the international competition for the Le Murate complex, in Firenze, 1987, based on a careful observation of the original drawings and the wooden model elaborated for the competition. The proposed design, which was not built, is a pathway-building structured in metal that overlaps the urban fabric of Firenze in the 1980s, in a visionary design approach which weaves visual relations within the city. The current research was carried out from the close observation of the drawings prepared by the architect for the competition, and the large wooden model, tri-dimensionally representing his design idea and solution, in addition to reading texts regarding the competition and the architect's proposal.

Keywords

Roberto Loeb, Le Murate, architecture drawings, unbuilt designs, visionary architecture.

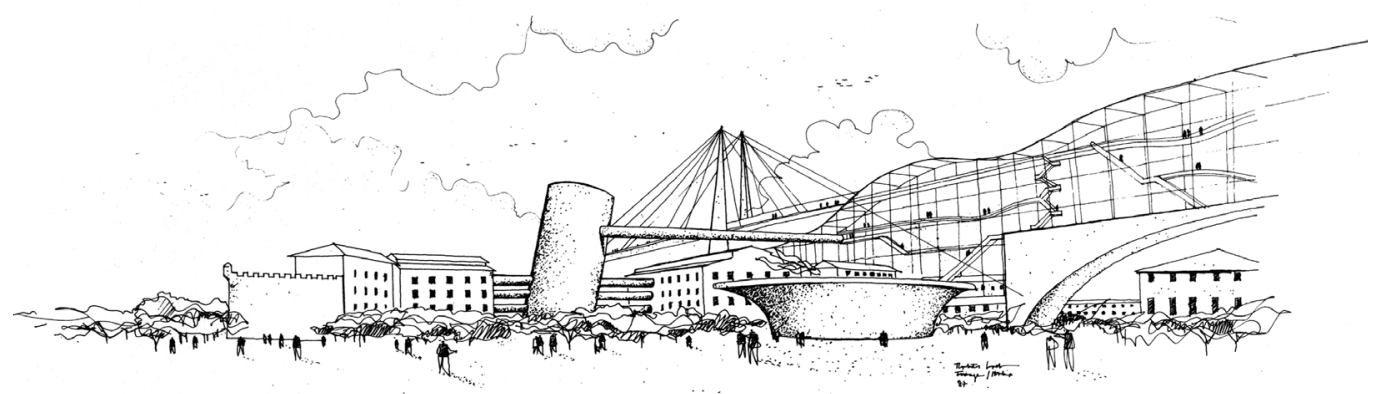




\section{Introduction}

At this point we must face a nagging suspicion: that the drawing can possibly be better than the reality.

[Cook 2008, p. I 6]

This contribution is part of a wider research path that aims at investigating architectural designs developed by both Brazilian architects in Italy and Italian architects in Brazil based on the international cooperation between Brazilian and Italian universities.

The research's objectives were to analyze the designs from the original drawings and registry, to rescue this knowledge registered in drawings and images, analyses and discussion of these designs, identifying architectural concepts and solutions. The study of unbuilt design works contributes to the understanding of the architectural propositions imagined by these modern architects and their insertion in such historical cities. Through the study of documents and original drawings, the derived graphic elaboration creates an increase in knowledge for its author and for those who will visualize it [Quattrini 2014].

Roberto Loeb graduated as an architect in Mackenzie University, is one of the most expressive Brazilian architects today. The Brazilian architect led a design team [I] able to develop a project for the Le Murate Complex that ended up among the proposals examined by the jury but not included into the final shortlist.

\section{The Le Murate Complex. Contextualization}

Esposito [Esposito 2019, p. 19] notes that Le Murate was a convent for 386 years, from I 42 I to 1807 , then a prison for 176 years, from 1807 to 1983. The architectural competition for the Le Murate in Firenze took place in 1987. In 1997 Renzo Piano was called to propose an idea to regenerate the place. The challenge was to combine respect for historical and architectural values and to integrate the proposal with the city.

Between 1985 and 1986 the Municipality launched international architecture competition An idea for the Murate: 161 proposals arrived from groups of Hungarian, Israeli, German, Italian, Brazilian, English, Swedish, Austrian and Argentinian architects. The first selection had been passed by ten projects, and to designate the winner among them it would have been necessary to launch a second competition, but numerous controversies about the quality of the entries prevented further developments.
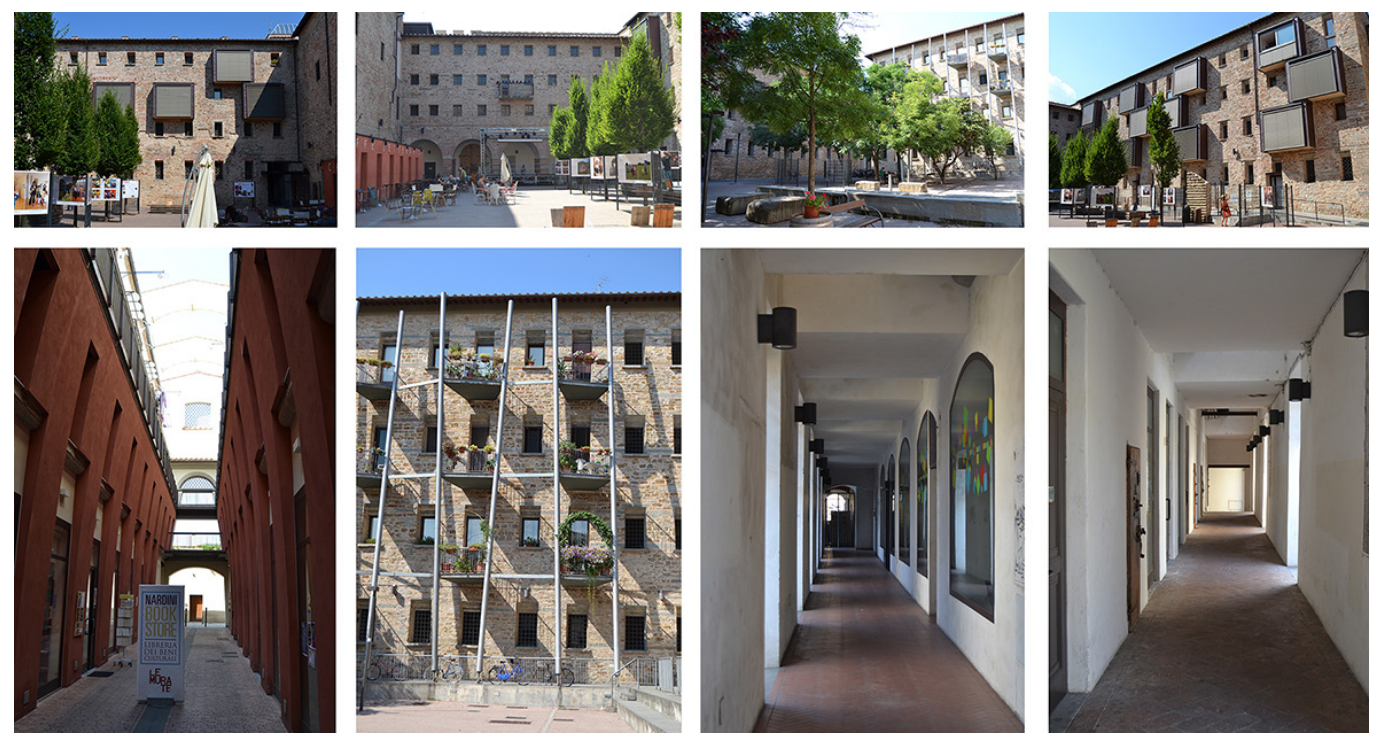
The final shortlist of 10 proposals was elaborated identifying those projects aiming at recovering the historic identity of the urban fabrics and organizing the main functions according to a vision of future based on 80's standards and following the public contest

announcement. The 10 selected entries were:

- entry 121: Gàbor Aczel

- entry 127: Michael Weiss

- entry 140: Christian Schaller, Helmut Theodor

- entry I55: Vinicio Somigli, Sergio Sozzi, Ugo Sanseverino, Antonella Cortesi, Piero Paoli, Bianca Bellestrero, Pierluigi Nervi

- entry 156: Roberto Maestro, Walter Di Salvo

- entry 164: Francisco Eduardo, Sanin Restrepo

- entry 191:Adolfo Natalini, Alessandro Chimenti, Augusto Mazzini, Francesco Re, Odoardo

Reali, Giancarlo Rossi, Salvatore Romano

- entry 199: Franco Landini, Sergio Agostinelli, Francesco Barbagli, Augusto Cagnardi, Luigi

Cerri, Vittorio Gregotti, Riccardo Roda

- entry 201: Sture Koinberg, Forshed Kjell

- entry 2 10: Bernd Stanzel, Kurt Puchinger,Werner Rosinak

The development of the former prisons was aimed at the following objectives: the increase of residential accommodation and related services, the encouraging of commercial activities, the improvement of recreational initiatives and the development of cultural activities [Conti 1988].

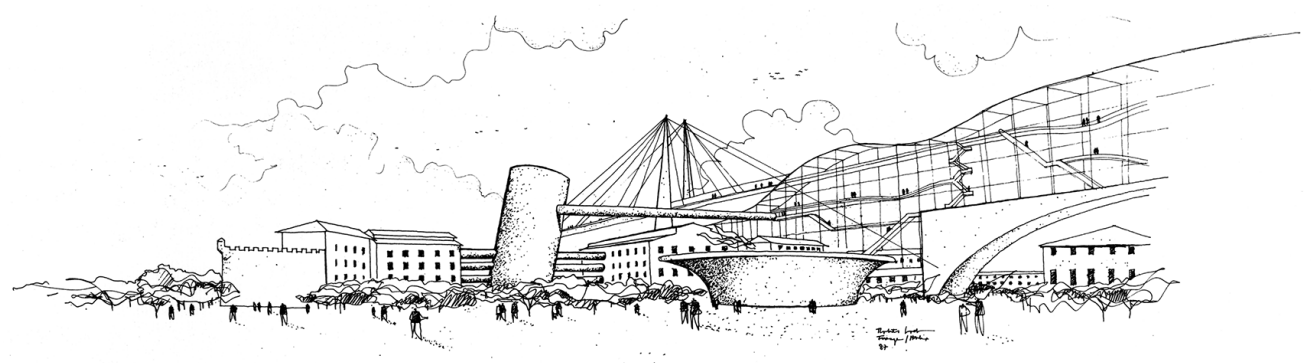

The project proposed by the architect Roberto Loeb. A study from the original drawings and the wooden model

The characteristic of the Loeb's plan was the construction of a megastructure dominating the city, in dialogue on an equal footing, as a modern presence, with the city's historic monuments. The structure intended to renew the urban fabric of the former prison complexes, elements of division, with the city's finer areas and with the hills of Oltrarno. A large raised pedestrian bridge created the connection, providing an all-inclusive vision which embraced the whole territory. The proposed new constructions were multi-purpose, from residential accommodations to cultural facilities, from commercial activities to tourist organizations Placed over on the urban grid, the large glass building extends for 380 meters, crossing the Arno river and reaching Piazzale Michelangelo, on the north-south axis of the city. The structure, which consists of a part of a glass building and other parts such as a pedestrian bridge, reaches I I 00 meters in length. The design's height competes with the duomo, with two large metal pillars reaching 60 meters, which support the first part of the pedestrian bridge.

The pedestrian bridge is 3 meters wide, crosses the Arno river and reaches the level of piazzale Michelangelo, creating a connection between the two sides of the river, forming a triangle between Santa Croce, the traditional historic center and piazza Michelangelo. On 
Fig. 3. Drawings of Roberto Loeb for the Le Murate competition, 1988
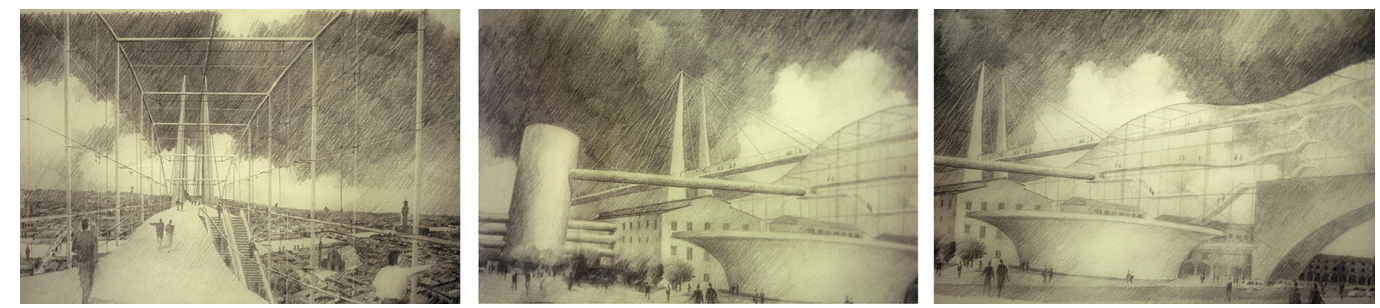

the way to the site, there are two accesses to the bridge on both sides of the river, on the Benvenuto Cellini and Zecca Vecchia roads, establishing connections between pedestrians walking through the city.

Along its extension, there is an open-air theater for 600 spectators in Palladian type: the stage and audience of this theater, were designed as a contemporary reproduction of the Vicenza theater designed by Palladio [Loeb 1987]. Metal containers are plug on this main structure, which houses exhibition spaces.

The internal spaces are organized in order to create routes, discoveries and visuals of the city, with references that refer to the Carceri by Piranesi, but now revisited in order to promote the freedom and experience of the new era. "Within the 'Large Glass' we have created vertical connections through elevators and escalators in a profusion of ascents and passages reminiscent of Piranesi.The horizontal connections are realized through sinuous or level walkways, creating a passage of surprises interrupted by seven large display cases, used for exhibitions and thematic installations" [Loeb 1987, p. 2].

The old prison building was transformed into a hotel, student' and elderly housing, as well as commercial and service spaces, which can be accessed through suspended walkways, which land in a cylindrical and inclined lobby, referring to the tower of Pisa.

The architect mentions the intention to use the urban fabric of Firenze to solve the design problem at hand, and to protect the piazza, creating a museum-route. After all, the city of Firenze is an open-air museum. "The 'Large Glass' is a test-tube through which the transparencies of daylight and the reflections of night blend all that goes on within the city, in a process of continuous transmutation. The bridge materializes this fusion and thereby will create a passage linking the historical center of Florence with the other side of the Arno River and the Santa Croce quartier. At the same time a communication will be established with the traditional model of the Ponte Vecchio" [Loeb 1987, p. 2].
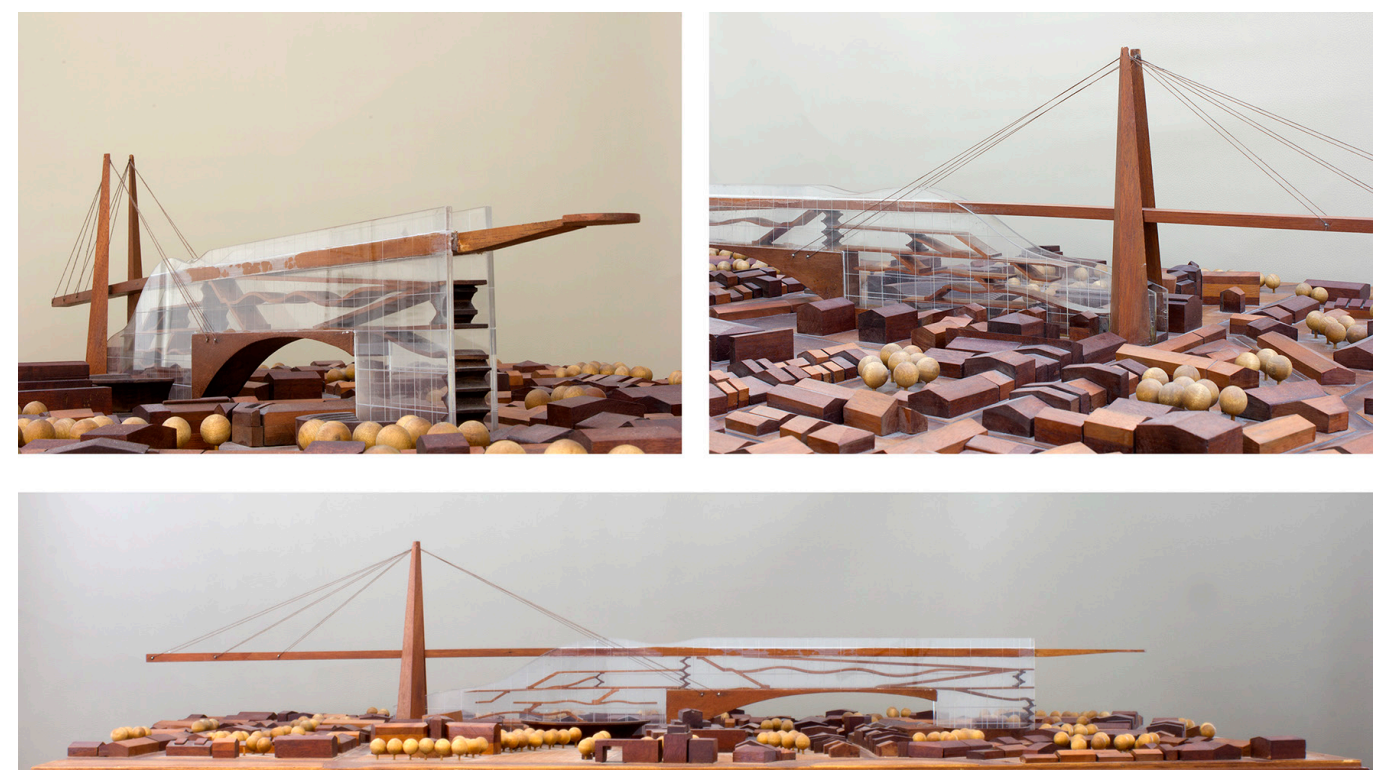
Along the proposed route there should be containers installed on the large structure of the walkway building. In this route, there would be an amphitheater, mentioning the traditional types of classical architecture. The old prison was supposed to become a hotel, and visitors could walk from Le Murate to piazzale Michelangelo with privileged views of the city of Firenze.

The air route takes place through the footbridge building, but the ground floor route also exists, connecting all activities along this area of the city. The main objective of this design proposition would be to enhance the region and regenerate abandoned areas.

The design indicates the architect's intention of exploring new languages. In that period Loeb reports that he designed and built several pavilions and stands, ephemeral architectures that made possible to experiment ideas, in addition to learn from the practice of assembly, and understanding the logic of the space node connectors for the metal structure. As Saggab (1984, p.50) observes, "an element that reappears almost as a constant in his works: the metallic structure. The ephemeral architecture, linked to the promotional area of exhibitions, marked the first works of the architect, then attracted by this type of structure that allows a quick and precise response, The need to design, build, assemble and dismantle pavilions in a short period, awoke in him the interest in a technology that was being developed in Europe and the United States".

Ideas aligned with the concepts of the Japanese Metabolists of the 1970s, as well as the works of German architect Frei Otto and American Buckminster Fuller.

\section{An analysis from original drawings and the physical model}

"The major groups of avant-garde visionaries of the 1960s flourished in the United Kingdom (Archigram), Italy (Superstudio), Austria (albeit some of them working elsewhere), France and Japan (Metabolists). These dramatis personae put on such a delightful charade in those years that I prefer not to describe the individuals in detail, but rather to let their drawings speak for themselves" [George R. Collins 1979, p. 252].

Cristiana Bartolomei and Alfonso Ippolito observe: "Representation amplifies the poetry of architecture as opposed to the prose of the construction. The ambition of architecture

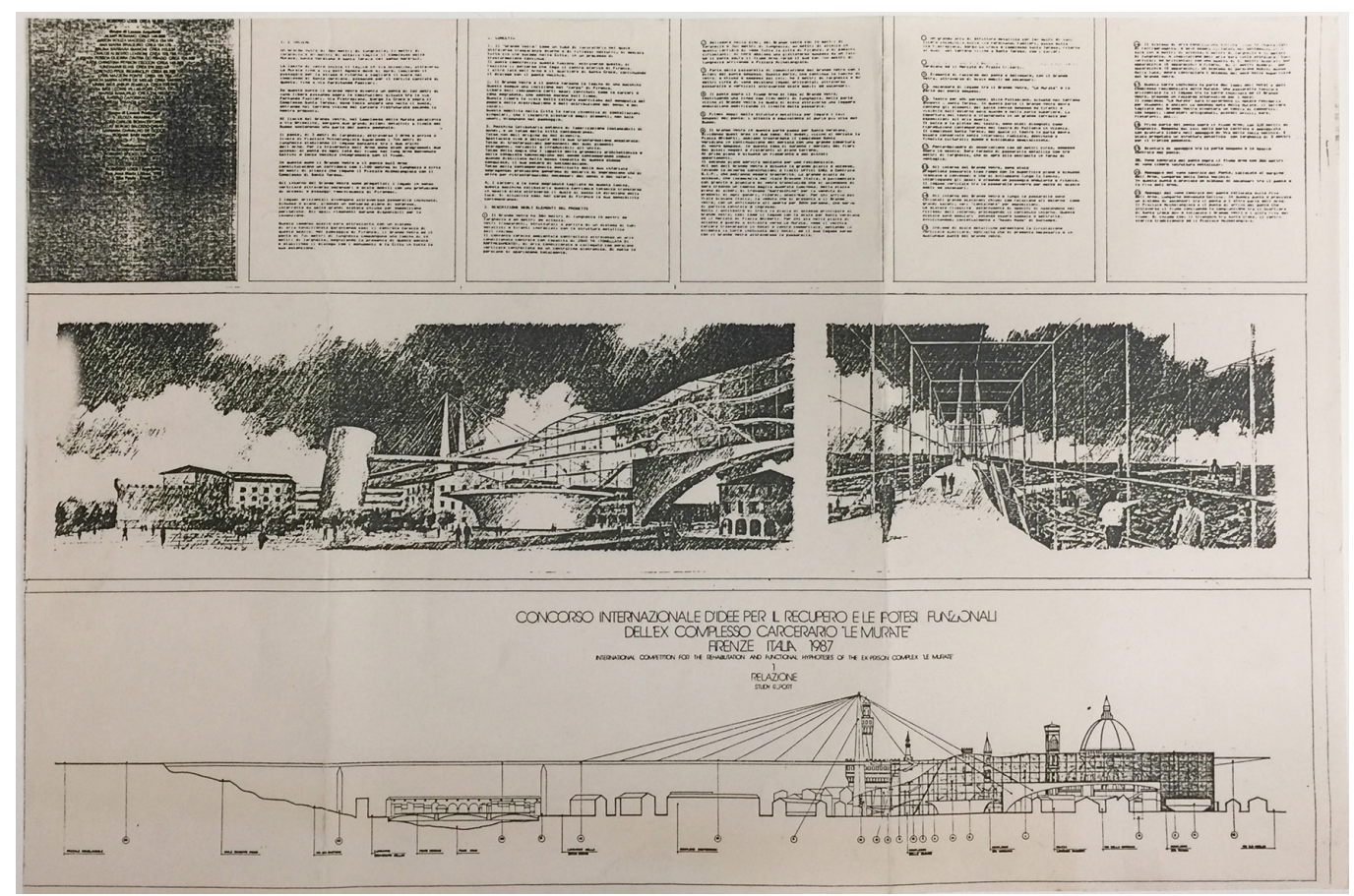


to remain pure creation of an exceptional mind is contrasted to the representation of the construction where such an ambition can never be realized. The visionary non-construction uncompromisingly represents the ideal of architecture just because its representation proves to be allusive, abstract, opaque, ungrammatical, fragmentary and free" [Bartolomei, Ippolito 2017, p. 10I].

Through the observation of the drawings we can analyze some important aspects. The points of view from which the drawings were made.

The first drawing presented (fig. I) was elaborated from the point of view of the observer who walks down the street and visualizes, on a diagonal, the complex at a certain distance. The large diagonal that extends beyond the limits of the frame, shows the proposed complex. The union of the diagonal with the extrapolation of the limits of the frame, gives the idea of dynamism and movement to what is being represented. Despite the monumentality of the complex, the large glass area creates an important transparency for the fluidity of the visuals. Through the observation of the wooden model, we can observe the relationship between full and empty becomes more evident, and we can verify that the Murate design creates an urban landmark with the two pillars that support the walkway building.
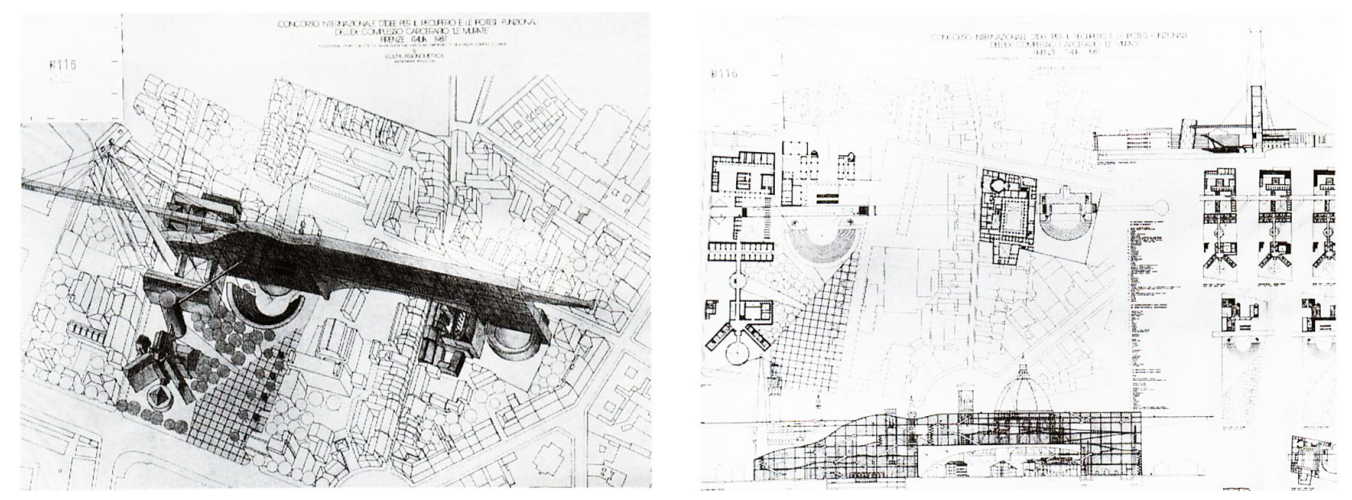

The drawings in figure 2 presents expressionist characteristics, with emphasis on people's perception of the large glass walkway and the possibility of viewing the city of Florence from an elevated and privileged point of view. In the other two drawings in figure 2, the point of view goes back to the observer who walks down the street observing the complex as a whole, which blends with the sky, emphasizing the transparency provided by the glass.

Massironi [Massironi 1982, p. 70] notes that the graphic representative process is characterized by the dialectic between emphasis and exclusion. In the drawings of the Murate design by Loeb you can see the emphasis on some aspects.

In the idea of movement, represented by several human figures in different locations. The transparent glazed building allows people to be seen walking on walkways and escalators.

Due to the shapes of the new building, diagonals and curves meeting, cables tumbled giving lightness while some elements of the composition provide solidity. The set also reveals the technology of the time.

The new building represented by dynamic forms, between lightness and solidity, symbolizing the dynamism and changes of modern life, while the old city is represented by orthogonal buildings with traditional roofs. However, the connection occurs at the union between the new and the old. The new building promotes a tour and allows people to view the beautiful old city.

The elevation and its importance in the representation of the idea. One of the drawings presented is an extensive elevation that reveals the profile of the city and the insertion of 
the new building, showing the relationships of height, scale and proportion between the new and the old. In this drawing we can note important buildings such as the Duomo, the tower of the Palazzo Vecchio and the Ponte Vecchio, in addition to understanding the location of the Arno river and the hill where Piazzale Michelangelo is located. The elevation allows one to understand the extent of Loeb's proposal, the glass walkway building and the bridge that reaches the Piazzale Michelangelo. The scale relationship between the new building, the city and the people.

An axonometric represents the general proposal inserted in the city map. In this drawing it is possible to understand the extension of the proposal on the ground level, with a large square, an amphitheater, in a scale relationship closer to the pedestrian and the street. Typical representation of the architecture of this period, the axonometric precisely designed, with views from the bottom up, were extensively explored by architects of the postmodern period, who aimed to reveal, in a more intense way, the space where the user could walk. As Massironi [Massironi 1982, p. 104] observes, axonometric is a well-structured system built on stable rules, able to represent objects while conserving metric qualities and providing, at the same time, a view of three-dimensionality and depth.

Drawing as a collage of elements belonging to different eras: classical, industrial, ephemeral, modern and postmodern language architecture. The collage, superposition, assimilation, distortion, provocation, imposition, conciliation and the 'contextualism' present in Loeb's proposal, brings us to the theory expressed in the book Collage City of 1978, which questions and criticizes the idea of the modern city with buildings constructed in isolation in a tabula rasa. In this sense, the proposal for a building that is inserted in the old city, in order to integrate with the existing one, with elements from different eras, is related to the thinking of the period. The proposal made possible from the study of the city map, its history, involving full and empty, in a balance between old and new.

The technique of drawing typical of the 1980s, with expressionist and visionary characteristics. Expressionist drawing is a representation that favors individual expression as opposed to issues such as materials and functions. As Pehnt notes: "If Expressionist architecture exist more on paper than in three-dimensional reality, it was because drawing is the medium that offers least resistance to imaginative vision" [Pehnt 1985, p. 6].

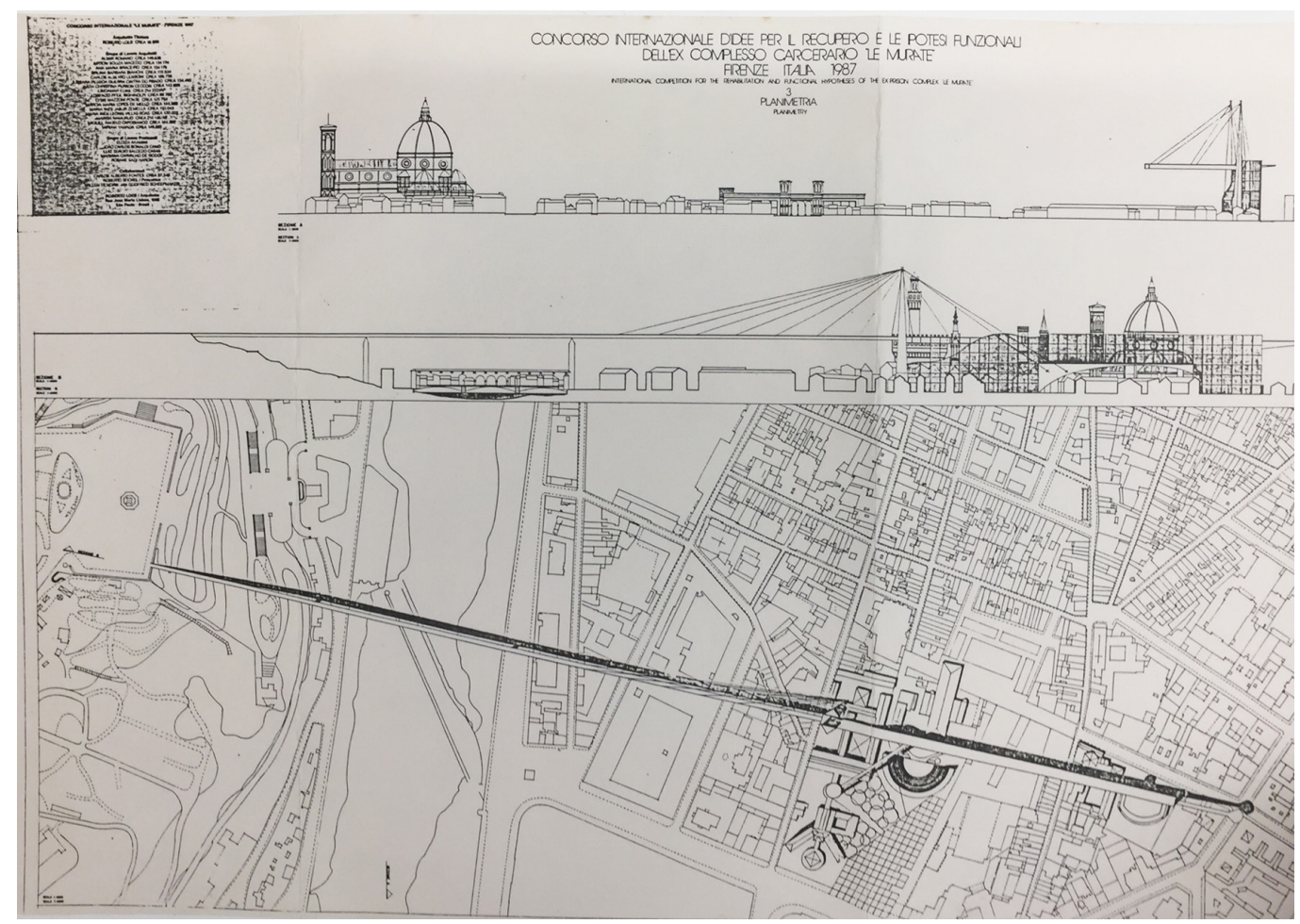




\section{Visionary architecture for weaving visuals of the city}

George Collins [Collins 1968] notes that the 1960s were characterized by a new direction of art and architecture that opened possibilities for expression and for creation. There was a great fascination for technology, a social anxiety coupled with an expression of the architects' imaginative vision.

Among the imaginary architectural reflections of the 1980s, Roberto Loeb's proposal speculates about the problems of modern urban life, creating a giant mega-structure [Banham 1976] that is based on concepts of freedom and multiple visuals, in opposition to the initial prison space.

Arthur Rosenblatt notes that modern visionaries were not limited to what was possible or likely, but what was necessary or desirable. And from this view, the mega structure is necessary: "These modern visionaries, however, are working with a new kind of form: the functional logic of the printed circuit or the rocket-launching device. Lines-structures, pathways, utilities-go where they have to go, exposed and direct [...] visions not for structures but for megastructures" [Rosenblatt 1968, p. 323].

In the case of the Loeb walkway building, there is an intention to bring together this element of urban infrastructure with the building's program, in a metallic mega-structure, characteristic to the language of the 1970s. With symbolic elements and traditional types of the classic Roman city, such as the tower, the great arch, the street, the amphitheater, the square, but now revisited by the period of the 1980s.

The original drawings and records of the competition do offer views and reflections on architecture and the city, which despite not having been built, exist in the drawings.

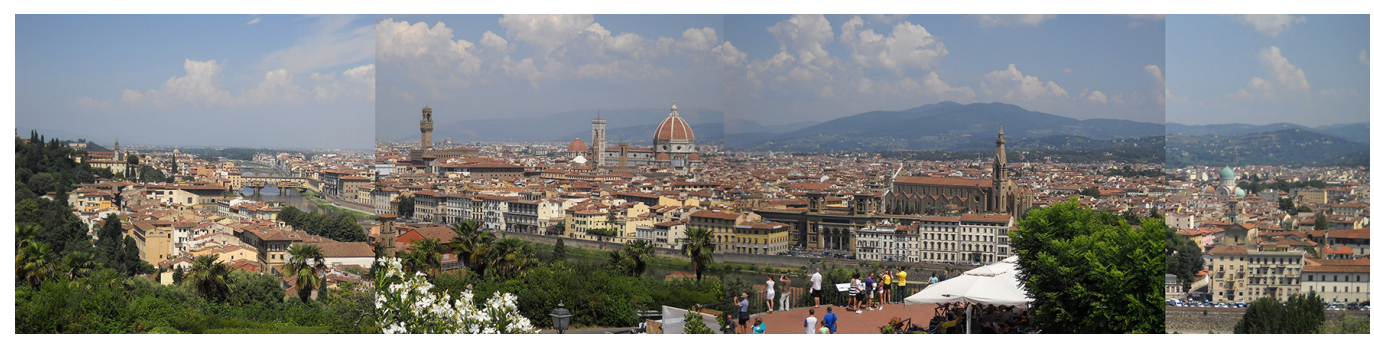

Notes

[I] The team members were: Marcia Maria Lopes De Mello, Maria Ines Leonis Villas Boas, Miriam Yamada, Almir Romano, Lorenzo Pfeil Sighinolfi, Katia Christina Persson Ceccon, Marisa Namurud, Ponte Lysis Mazzoni, Elias Lindamar, Carlos Alberto Lensoni, Souza Ayrton Macedo, Jussara Cintra do Prado, Miguel Capobianco, Zemella Jabur, Ana Maria Braceiro and Bruna Barbara Bianchi.

\section{References}

Banham Reyner (1976). Megastructure. Urban futures of the recent past. New York:Thames and Hudson.

Bartolomei Cristiana, Ippolito Alfonso (2017). Le metamorfosi della rappresentazione: rappresentare l'immaginario. In di Luggo Antonella, Giordano Paolo et al. (eds.) Territories and frontiers of Representation. 39th International Conference of Representation Disciplines Teachers. Naples 14-I I 6 September 20 17. Roma: Gangemi Editore, pp. I0 I- 06.

Collins George R. (1968). The New Visionary Tradition in Architecture. In The Metropolitan Museum of Art Bulletin, New Series, v. 26. n. 08, Apr. 1968, pp. 310-321.

Collins George R. (1979). Visionary Drawings of Architecture and Planning: 20th Century through the 1960s. In Art Journal, Vol.38, 4/1979, pp. 244-256.

Conti Sergio (ed.) (1988). Un'idea per le Murate progetti ammessi alla prima fase del concorso internazionale bandito dal Comune di Firenze. Firenze, ex-carcere di Santa Verdiana, 24 settembre-30 ottobre 1988. Firenze: Electa.

Cook Peter (2008). Drawing. The motive force of architecture. Hoboken: John Wiley \& Sons 
Esposito Vincenzo (2019). Recuperare le Murate. Da carcere a cittá residenze popolari, cultura, commercio e servizi pubblici. Firenze: Aiòn Edizioni.

Florio Wilson, Tagliari Ana, Melachos Corres Felipe, Rossato Luca (2019). The unbuilt Ponte dell'Accademia in Veniza by Oscar Niemeyer. In Belardi Paolo (ed.). Reflection the art of drawing/the drawing of art. 4 I $^{\text {th }}$ International Conference of Representation Disciplines Teachers Proceedings. Perugia I5- 17 September 2019 Roma: Gangemi Editore, pp. I I93- 1200.

Fraser lain, Henmi Rod (1993). Envisioning Architecture. An Analysis of Drawing. NY: John Wiley \& Sons.

Giordano Andrea, Bruzelius Caroline, Huffman Lanzoni Kristine (20 I 8).Visualizing Venice/Visualizing Cities. In Bertocci Stefano (ed.). Programmi multidisciplinari per l'internazionalizzazione della ricerca. Patrimonio culturale, Architettura e Paesaggio. Firenze: Didapress.

Harbison Robert (1991). The Built, the Unbuilt and the Unbuildable. In Pursuit of Architectural Meaning. London: Thames and Hudson.

Loeb Roberto (1987). Concurso Internacional Le Murate. Memorial descritivo. O partido geral (s.e.).

Massironi Manfredo (1982).Ver pelo desenho. Aspectos técnicos, cognitivos, comunicativos. São Paulo: Martins Fontes.

Ranzani Ermanno (2015). Firenze: concorso internazionale di idee per il recupero dell'ex-complesso carcerario dell Murate. In Domus 692/1988, pp. 38-53.

Revista Monolito. LoebCapote. Edição 25, 2015.

Rosso Silvana Maria (20I I). Roberto Loeb: arquiteto. São Paulo: BEl Comunicação.

Rowe Colin, Koetter Fred (1978). Collage City. Cambridge:The MIT Press.

Sabbag Hayfa Y ( 1 984). Forma e espaço na arquitetura de Roberto Loeb. In Revista Módulo, edição 80/I984, pp.50-63.

Tagliari Ana (20।8). Modelos conceituais de percurso e circulação no projeto de arquitetura. In Revista 5\% Arquitetura + Arte, São Paulo, ano 13, volume I, número 16.

\section{Authors}

Ana Tagliari, University of Campinas, tagliari.ana@gmail.com

Wilson Florio, Mackenzie Presbyterian University, wilsonflorio@gmail.com

Luca Rossato, Università di Ferrara, rsslcu@unife.it

Felipe Corres Melachos, Anhembi Morumbi University, felipe.corres@gmail.com

To cite this chapter. Tagliari Ana, Florio Wilson, Rossato Luca, Corres Melachos Felipe (2020). Visionary drawings for weaving visuals of the city Roberto Loeb's design for the international competition for ideas for the recovery of the Le Murate complex. In Arena A., Arena M., Brandolino R.G., Colistra D., Ginex G., Mediati D., Nucifora S., Raffa P. (a cura di). Connettere. Un disegno per annodare e tessere. Atti del $42^{\circ}$ Convegno Internazionale dei Docenti delle Discipline della Rappresentazione/Connecting. Drawing for weaving relationships. Proceedings of the 42th Internationa Conference of Representation Disciplines Teachers. Milano: FrancoAngeli, pp. 2778-2786. 